\title{
High-profile departure ends genome institute's charmed run
}

The personal divorce was final two years ago. The professional one dragged on until April, when Claire Fraser-Liggett left the organization headed by her ex-husband, genome scientist J. Craig Venter, to hoist her own flag over a new institute at the University of Maryland in ๖ Baltimore.

As she left, the organization she shepherded to star status in the scientific world melted behind her: on 11 April, The Institute for Genomic Research (TIGR), over which Fraser-Liggett had presided since 1998, was absorbed into the J. Craig Venter Institute (JCVI) and ceased to exist.

Fraser-Liggett says her departure was spurred by the decision in October to make TIGR a division of the JCVI. "It was just unclear to me what my role in the new organization would be," she says. "[But] I want to emphasize that I am not looking to escape a bad situation."

Venter, who is president and chair of the 500employee JCVI, insists that little has changed. Genome sequencing, he said in a press release, will remain a "cornerstone" of the institute's activities, as will the microbial and plant sequencing that were TIGR's province.

TIGR's dissolution completes a process that was set in motion six months earlier, says Bob Strausberg, JCVI's deputy director. "It's all been driven by scientific opportunity," he says.

In November, Fraser-Liggett's second husband, Steven Liggett, director of the cardiopulmonary genomics program at the University of Maryland, bumped into Bruce Jarrell, the medical school's vice dean for research. Liggett then told Jarrell "that the time might be right to entice me away from TIGR," says Fraser-Liggett.
Jarrell called Fraser-Liggett soon after and by late March her new job was finalized. "This opportunity at Maryland was the right opportunity at the right time," she says. She plans to begin work in early May as head of the university's nascent Institute of Genome Sciences, with an eventual staff of 150 and a research budget of up to $\$ 40$ million.

Some number of TIGR's 18 faculty scientists are expected to follow her, but she declines to specify how many. "There have been some who have suggested that I'm somehow raiding the organization," she says. "Let's just say there are several offers outstanding."

One scientist who has worked with both Venter and Fraser-Liggett says the new institute will offer TIGR scientists the chance to continue independent research under Fraser-Liggett's hands-off style, rather than taking direction from Venter. "It will be very telling how many go and how many stay," he says. "It's basically a Craig versus Claire choice."

Venter founded TIGR in 1992, but after decoding Hemophilus influenzae, the first microbial genome, he decamped in 1998 to found Celera Genomics and sequence the human genome. Fraser-Liggett, then still Venter's wife, remained as president of TIGR. During her nine-year tenure as president, she estimates, TIGR scientists sequenced more than 200 genomes. At its height, the institute doubled its staff to more than 300 and nearly tripled its yearly research budget to $\$ 60$ million. TIGR became the undisputed leader in microbial genomics and Fraser-Liggett the world's most highly-cited microbiologist.

Under Fraser-Liggett, "TIGR evolved in profound ways," says W. Richard McCombie, a molecular biologist at the Cold Spring Harbor Laboratory in New York. "The science became different and better, I have to say, so there's concern about a return to what it was like before," he says. "And there's some real concern about the future of the place."

The move makes Fraser-Liggett, who in style if not substance has long been overshadowed by Venter, at long last the undisputed queen of her own castle. It's also a coup for the University of Maryland. "They're not on the map in genomics," says McCombie. "Bringing her in instantly puts them in a very high-profile position."

Meredith Wadman, Washington DC

\section{Will there be an HIV vaccine in the next ten years?}

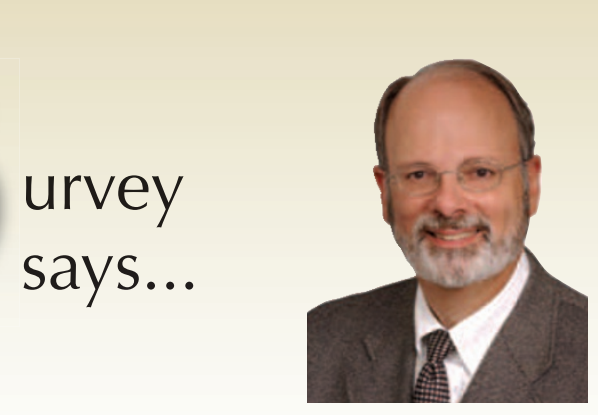

It is too early to tell. If the current adenovirus-based trials show some degree of protection or control of viral load, then we have a substantial beachhead from which to work.

Barton Haynes
director
Center for HIV-AIDS
Vaccine Immunology

I think we will have something that modulates infection soon. [But] will we have something in a vial that's being distributed in the developing world? Highly unlikely.

Bruce Walker professor of medicine Harvard University 